\title{
Molecular Single-cell Analysis Reveals that CD5-positive Peripheral Blood B Cells in Healthy Humans are Characterized by Rearranged $V_{\mathrm{K}}$ Genes Lacking Somatic Mutation
}

\author{
Matthias Fischer, Ulf Klein, and Ralf Küppers \\ Institute for Genetics, University of Cologne, 50931 Cologne, Germany
}

\begin{abstract}
$B$ cells expressing the CD5 cell surface antigen are involved in certain $\mathrm{B}$ cell malignancies and autoimmune diseases. From studies in the mouse, it emerged that $\mathrm{CD5}^{+} \mathrm{B}$ cells represent a separate lineage of $B$ lymphocytes that, in contrast to conventional $\left(\mathrm{CD5}^{-}\right) \mathrm{B}$ cells, are not driven into $\mathrm{T}$ cell-dependent immune responses in which rearranged variable $(V)$ region genes are diversified by somatic hypermutation. Against this background it came as a surprise that human disease-involved CD5-positive autoreactive B cells as well as B cell chronic lymphocytic leukemias can harbor somatically mutated $\mathrm{V}$ region genes. Recent $\mathrm{V}$ gene analyses on $\mathrm{CD5}^{+} \mathrm{B}$ cells in healthy adults did not give rise to a clear picture about the fraction of somatically mutated among all $\mathrm{CD5}^{+} \mathrm{B}$ cells. In this work we used a molecular single-cell analysis to determine reliably the frequency of mutated $\mathrm{CD}^{+} \mathrm{B}$ cells in healthy humans: single, $\kappa$ light chain-expressing $\mathrm{CD5}^{+}$peripheral blood $\mathrm{B}$ cells were isolated by flow cytometry, and rearranged $\mathrm{V}_{\mathrm{K}}$ genes were amplified by PCR. From one donor, $\mathrm{CD5}^{+} \mathrm{CD}^{-1}{ }^{+} \mathrm{B}$ cells were analyzed. Since $\mathrm{CD5}^{+} \mathrm{B}$ cells were found among $\operatorname{IgM}^{+} \mathrm{IgD}^{+}$ and $\mathrm{IgM}^{+} \mathrm{IgD}^{-}$cells (but almost not among class-switched cells) from two other donors, individual cells corresponding to these IgM-expressing subsets were investigated separately. The sequence analysis of rearranged $V_{k}$ genes revealed that most if not all $\mathrm{CD5}^{+} \mathrm{B}$ cells in healthy humans carry unmutated $\mathrm{V}$ region genes. From one of the donors, a novel polymorphic $\mathrm{J}_{\mathrm{K}} 2$ gene segment was identified. To explain the discrepancy between the frequent occurrence of disease-associated somatically mutated $\mathrm{CD5}^{+} \mathrm{B}$ cells and the low incidence or absence of somatic mutation in normal $\mathrm{CD5}^{+} \mathrm{B}$ cells, we speculate that $\mathrm{CD5}^{+} \mathrm{B}$ cells usually do not participate in germinal center reactions, but if they occasionally do so, they may be at an increased risk to become involved in autoimmune diseases or B cell malignancies. (J. Clin. Invest. 1997. 100:1667-1676.) Key words: B1 cells • CD5 • single cell PCR • somatic hypermutation • variable region genes
\end{abstract}

M. Fischer and U. Klein contributed equally to this work.

Address correspondence to Dr. Ralf Küppers, University of Cologne, University Clinics, LFI E4 R706, Joseph-Stelzmannstr. 9, 50931 Cologne, Germany. Phone: 49-221-478-4490; FAX: 49-221-4786383; E-mail: rkuppers@mac.genetik.uni-koeln.de

Received for publication 9 April 1997 and accepted in revised form 7 August 1997.

J. Clin. Invest.

(C) The American Society for Clinical Investigation, Inc. 0021-9738/97/10/1667/10 \$2.00

Volume 100, Number 7, October 1997, 1667-1676

http://www.jci.org

\section{Introduction}

B lymphocytes expressing the CD5 antigen are the predominant $\mathrm{B}$ cell population early in life $(1,2)$. Later, their number is reduced, and $\mathrm{CD}^{+} \mathrm{B}$ cells account for $\sim 10-25 \%$ of peripheral blood $(\mathrm{PB})^{1} \mathrm{~B}$ cells in man (1-3). These cells are also found in spleen and tonsil at a comparable frequency (1-3). One characteristic feature of $\mathrm{CD}^{+} \mathrm{B}$ cells (also called B1a cells) is that many of them produce autoreactive antibodies, which are usually polyreactive (4). Numbers of $\mathrm{CD}^{+} \mathrm{B}$ cells are elevated in certain autoimmune diseases, and in some of these cases $\mathrm{CD}^{+} \mathrm{B}$ cells producing high-affinity autoantibodies have been detected (4-7). A relationship between $\mathrm{CD}^{+} \mathrm{B}$ cells and autoimmunity is further suggested by the finding that mouse strains harboring elevated levels of $\mathrm{CD}^{+} \mathrm{B}$ cells are prone to autoimmune diseases (1). $\mathrm{CD}^{+} \mathrm{B}$ cells are also involved in certain B cell malignancies. More than $95 \%$ of cases of $\mathrm{B}$ cell chronic lymphocytic leukemia (B-CLL), the most common leukemia of adults in the Western world, express CD5 (1). In addition, CD5 is regularly found on tumor B cells in small lymphocytic lymphoma (1).

The origin of $\mathrm{CD}^{+} \mathrm{B}$ cells in humans and mice is much debated $(1,8)$. Since CD5 expression can be induced in vitro on CD5-negative B cells, it has been suggested that CD5 represents an activation marker (9). In the induction/selection model, B cells recognizing autoantigens with low affinity are selected to become $\mathrm{CD}^{+} \mathrm{B}$ cells (10). On the other hand, transfer experiments in mice support a dual-lineage model that states that CD5-positive and CD5-negative (conventional) B cells represent distinct lineages of B cells (11). Those transfer experiments also revealed that $\mathrm{CD}^{+} \mathrm{B}$ cells repesent a selfreplenishing population of long-lived lymphocytes $(12,13)$.

Immunoglobulin $\mathrm{V}$ genes expressed by $\mathrm{CD}^{+} \mathrm{B}$ cells have been the subject of a large number of studies. A sequence analysis of immunoglobulin $\mathrm{V}$ region genes allows one to gain insight into the stage of differentiation of the respective $B$ cell. Immature and naive $B$ cells carry unmutated variable $(V)$ region genes (14-17). Somatic mutations are introduced into rearranged $\mathrm{V}$ genes in the course of $\mathrm{T}$ cell-dependent immune reactions $(14,18)$. This process takes place in the microenvironment of the germinal center (GC) (19-21). Consequently, somatically mutated $\mathrm{V}$ region genes are found in GC B cells and their descendants, i.e., memory B cells and GC-derived plasma cells $(16,17,21)$. Whereas murine $\mathrm{CD}^{+} \mathrm{B}$ cells express unmutated $\mathrm{V}$ region genes (22-24), the situation appears to be different in the human: somatically mutated $\mathrm{V}$ genes have been described in cases of CD5-expressing B-CLL (2528 ) and in $\mathrm{CD}^{+} \mathrm{B}$ cells producing high-affinity autoantibodies

1. Abbreviations used in this paper: B-CLL, B cell chronic lymphocytic leukemia; CDR, complementarity-determining region; $\mathrm{GaH}$, goat anti-human; GC, germinal center; MC, mononuclear cells; PB, peripheral blood. 
$(5,6)$. Moreover, somatic mutations have been reported to be present in $\mathrm{V}$ genes of $\mathrm{CD}^{+} \mathrm{B}$ cells isolated from healthy donors $(16,29,30)$. These findings suggest that in terms of somatic mutation, there is no difference between $\mathrm{CD}^{+} \mathrm{B}$ cells and conventional B cells in humans.

Two findings prompted us to reinvestigate the issue of the occurrence and frequency of $\mathrm{CD}^{+} \mathrm{B}$ cells carrying somatically mutated $\mathrm{V}$ genes in healthy individuals: first, most $\mathrm{CD}^{+} \mathrm{B}$ cells are found among $\operatorname{IgM}^{+} \operatorname{IgD}^{+}$B lymphocytes $(2,3)$. The vast majority of these naive $\mathrm{B}$ cells, however, carry unmutated $\mathrm{V}$ region genes $(15-17,31)$, which also implies that most $\mathrm{CD}^{+} \mathrm{B}$ cells express unmutated $\mathrm{V}$ genes. Obviously, this result contrasts with the $\mathrm{V}$ gene studies on $\mathrm{CD}^{+} \mathrm{B}$ cells in healthy individuals $(16,29,30)$. A possible explanation for this discrepancy might be that a small subset of cells with mutated $\mathrm{V}$ region genes among $\operatorname{IgM}^{+} \mathrm{IgD}^{+} \mathrm{B}$ cells could have been missed in the analyses of $\operatorname{IgM}^{+} \operatorname{IgD}^{+} \mathrm{B}$ cells, or that the mutated $\mathrm{V}$ genes in those studies $(16,29,30)$ were derived from $\mathrm{IgD}^{-} \mathrm{CD}^{+} \mathrm{B}$ cells. Second, we recently showed that human peripheral blood B lymphocytes carrying somatically mutated $\mathrm{V}$ region genes, i.e., $\operatorname{IgM}^{+} \operatorname{IgD}^{-}$(IgM-only) and class-switched B cells, harbor elevated levels of mRNA coding for immunoglobulin when compared with naive $\operatorname{IgM}^{+} \mathrm{IgD}^{+} \mathrm{B}$ cells (31). Since the studies on $\mathrm{CD}^{+} \mathrm{B}$ cells of healthy donors were carried out by amplifying $\mathrm{V}$ region gene transcripts from cell populations (16, $29,30)$, those investigations might be biased towards somatically mutated $\mathrm{V}$ genes.

To overcome these problems, we sorted single $\mathrm{CD}^{+} \mathrm{B}$ cells by flow cytometry, and amplified rearranged $V_{\kappa}$ genes from genomic DNA of individual cells. PCR products were sequenced directly. This approach should allow one to determine reliably the frequency of $\mathrm{CD}^{+} \mathrm{B}$ cells carrying mutated $\mathrm{V}$ region genes.

\section{Methods}

Isolation of single cells and flow cytometry. $60-100 \mathrm{ml} \mathrm{PB}$ was obtained from three male, healthy donors ages 27-35. PB mononuclear cells (MC) were purified by Ficoll-Isopaque density centrifugation, and were incubated with unconjugated antihuman $\kappa$ light chain (IgG1-isotype, Becton Dickinson, Mountain View, CA) for $15 \mathrm{~min}$ on ice. After washing, the cells were incubated with goat anti-mouseIgG1 microbeads (Miltenyi Biotec Inc., Bergisch Gladbach, Germany) for $20 \mathrm{~min}$ at $4^{\circ} \mathrm{C}$. Subsequently, $\kappa$-expressing B cells were enriched to $>90 \%$ by magnetic cell separation using the MiniMACS ${ }^{\mathrm{TM}}$ system (Miltenyi Biotec Inc.) (15). For isolation of single $\mathrm{CD}^{+} \mathrm{CD} 19^{+}$ $B$ cells from donor HK, the cell suspension was incubated with antiCD5-PE and anti-CD19-FITC (Becton Dickinson). The cell suspensions from the other two donors were stained with anti-CD5-FITC (Becton Dickinson), goat anti-human (GaH)-IgM-PE (Sigma Chemical Co., München, Germany), and biotinylated GaH-IgD (Southern Biotechnology Associates, Birmingham, AL). After washing, GaHIgD was developed with Streptavidin-CyChrome (PharMingen, San Diego, CA). All staining procedures were performed for $15 \mathrm{~min}$ on ice. Using a FACS 440 (Becton Dickinson), single к-expressing B cells of the following $\mathrm{B}$ cell fractions were sorted directly into PCR reaction tubes containing $20 \mu \mathrm{l}$ PCR buffer and $20 \mathrm{ng} 5 \mathrm{~S} \mathrm{rRNA}$ : CD5 ${ }^{+} \mathrm{CD} 19^{+}$ $\mathrm{B}$ cells (donor $\mathrm{HK}$ ), $\mathrm{CD}^{-} \mathrm{IgM}^{+} \mathrm{IgD}^{-} \mathrm{B}$ cells, $\mathrm{CD}^{+} \mathrm{IgM}^{+} \mathrm{IgD}^{-} \mathrm{B}$ cells, and $\mathrm{CD}^{+} \mathrm{IgM}^{+} \mathrm{IgD}^{+} \mathrm{B}$ cells (donors $\mathrm{RK}$ and $\mathrm{AB}$ ). In addition, a fraction of peripheral blood mononuclear cells (PBMC) was stained with anti-CD3-FITC (Becton Dickinson), and single T cells $\left(\mathrm{CD}^{+}\right)$were sorted into reaction tubes as described above.

The size of $\mathrm{CD}^{+} \mathrm{IgM}^{+} \mathrm{IgD}^{+}$as well as $\mathrm{CD}^{+} \mathrm{IgM}$-only PB B cells and their CD5-negative counterparts was determined by forward scatter analysis. The populations did not differ from each other in this respect.

For analysis of isotype-switched B cells with regard to CD5-expression, PBMC of seven healthy adult donors were incubated with antiCD19 microbeads (Miltenyi Biotec Inc.) for $20 \mathrm{~min}$ at $4^{\circ} \mathrm{C}$, and $\mathrm{CD}_{1} 9^{+}$B cells were enriched to $99 \%$ by MiniMACS ${ }^{\mathrm{TM}}$. The B cellenriched cell suspensions were stained with anti-CD5-PE, GaH-IgD, and with either GaH-IgG-FITC (Southern Biotechnology Associates) or rabbit anti-human-IgA F $\left(\mathrm{ab}^{\prime}\right)_{2}$-FITC (Dako Corp., Hamburg, Germany) as described above. Samples were analyzed on a FACScan (Becton Dickinson).

To analyze tonsillar non-GC B cells consisting of naive as well as memory B cells (17) for expression of CD5, this fraction was enriched by depleting GC B cells $\left(\mathrm{CD} 38^{+}\right)$and T cells using the MACS system (Miltenyi Biotec Inc.). Tonsillar MC were incubated with anti-CD3 microbeads (Miltenyi Biotec Inc.) and unconjugated anti-CD38 (IgG1isotype; Becton Dickinson) for $20 \mathrm{~min}$ at $4^{\circ} \mathrm{C}$, and after washing with anti-IgG1 microbeads. After magnetic cell separation, tonsillar nonGC B cells were enriched to $\sim 85 \%$. This fraction was analyzed for surface expression of $\mathrm{CD} 5$ on $\mathrm{IgM}^{+} \mathrm{IgD}^{+}$and IgM-only cells as well as on isotype-switched memory B cells using the staining procedures described above.

Single cell PCR and sequencing of PCR products. Single cells were incubated in $20 \mu \mathrm{l}$ PCR buffer containing $0.5 \mathrm{mg} / \mathrm{ml}$ proteinase $\mathrm{K}$ for $1 \mathrm{~h}$ at $50^{\circ} \mathrm{C}$. The enzyme was inactivated by denaturation at $95^{\circ} \mathrm{C}(10$ $\mathrm{min}$ ). For the first round of amplification, a primer mix consisting of four $\mathrm{V}_{\kappa}$ family-specific primers, which recognize sequences in the framework region $I$ of the members of the $V_{k} 1-4$ gene families, and a downstream primer specific for a sequence $3^{\prime}$ of $\mathrm{J}_{\mathrm{K}} 5$ was used (see Table I). This approach prevents amplification of $\mathrm{V}_{\mathrm{k}}-\mathrm{J}_{\mathrm{K}} 1,2,3$ \& 4 rearrangements that have been located away from the $C_{\kappa}$ locus by inversion (32), and therefore presumably do not undergo somatic hypermutation due to their large distance from both the $\kappa$ intron and the $\kappa 3^{\prime}$-enhancer (33). Owing to the small distance between the five $J_{\mathrm{K}}$ gene segments, however, $\mathrm{V}_{\mathrm{K}} \mathrm{J}_{\mathrm{K}}$ rearrangements lying in the proper location in the Igא locus can be efficiently amplified with a primer $3^{\prime}$ of the last $\mathbf{J}_{\kappa}$ gene. The first round of amplification was carried out in the same reaction tube in a 50- $\mu$ l volume containing Expand ${ }^{\mathrm{TM}}$ High Fidelity buffer (Boehringer Mannheim, Mannheim, Germany), 1.75 $\mathrm{mM} \mathrm{MgCl} 2,100 \mu \mathrm{M}$ dATP, dGTP, dTTP, and dCTP, respectively, 50 $\mathrm{nM}$ of each primer, and $2.5 \mathrm{U}_{\text {Expand }}{ }^{\mathrm{TM}}$ High Fidelity polymerase (Boehringer Mannheim). The amplification program consisted of 35 cycles of $60 \mathrm{~s}$ at $95^{\circ} \mathrm{C}, 30 \mathrm{~s}$ at $61^{\circ} \mathrm{C}$, and $80 \mathrm{~s}$ at $72^{\circ} \mathrm{C}$, followed by a final incubation step at $72^{\circ} \mathrm{C}$ for $5 \mathrm{~min}$. Enzyme was added after the first denaturation step. For the second round of amplification, the same $V_{K}$ family-specific primers were used together with three internal $J_{K}-$ specific primers hybridizing to the five human $J_{K}$ gene segments (see Table I). The second round of amplification was performed in separate reactions for each of the four $V_{\kappa}$ primers using $1 \mu l$ of the firstround reaction mixture in a $50-\mu l$ volume containing $10 \mathrm{mM}$ Tris$\mathrm{HCl}, \mathrm{pH} 8.3\left(20^{\circ} \mathrm{C}\right), 50 \mathrm{mM} \mathrm{KCl}, 2.0 \mathrm{mM} \mathrm{MgCl} 2,100 \mu \mathrm{M}$ dATP, dGTP, dTTP, and dCTP, respectively, $125 \mathrm{nM}$ of each primer, and $0.7 \mathrm{U}$ Taq DNA polymerase (Boehringer Mannheim). The amplification conditions were as described above, except that the elongation step at $72^{\circ} \mathrm{C}$ was carried out for $60 \mathrm{~s}$, and 40 cycles were applied. PCR products were purified by gel electrophoresis. An aliquot of the isolated DNA was sequenced directly with ${ }^{32} \mathrm{P}$-labeled oligonucleotides of the second round using the dsDNA Cycle Sequencing System (GIBCO BRL, Eggenstein, Germany) as recommended by the supplier. Nucleotide sequences were analyzed using DNASIS ${ }^{\mathrm{TM}}$ software (Pharmacia, Freiburg, Germany). In some cases, it was not possible to determine by sequence analysis which of the five $J_{\kappa}$ gene segments had been rearranged. In these cases, the second round of PCR was repeated using the respective $V_{k}$ family-specific primer together with each of the $J_{\kappa}$-specific primers in separate reactions ( $J_{\kappa}$ typing).

Statistical analysis. Differences in the proportions of cells carrying mutated $\mathrm{V}_{\mathrm{\kappa}}$ genes, and differences in the proportions of potentially functional $V_{k}$ genes with complementarity-determining region 


\begin{tabular}{ll}
\hline Oligonucleotide & \multicolumn{1}{c}{ Sequence } \\
\hline $\mathrm{V}_{\mathrm{k}} 1$ & $5^{\prime}$-GACATCC $<$ AG $>$ G $<$ AT $>$ TGACCCAGTCTCC $<$ AT $>$ TC-3' \\
$\mathrm{V}_{\mathrm{k}} 2$ & $5^{\prime}$-CAG $<$ AT $>$ CTCCACTCTCCCTG $<$ CT $>$ CCGTCA-3' \\
$\mathrm{V}_{\mathrm{k}} 3$ & $5^{\prime}$-TTGTG $<$ AT $>$ TGAC $<$ AG $>$ CAGTCTCCAG $<$ GC $>$ CACC-3' \\
$\mathrm{V}_{\mathrm{k}} 4$ & $5^{\prime}$-AGACTCCCTGGCTGTGTCTCTGGGC-3' \\
$3^{\prime} \mathrm{J}_{\mathrm{k}} 5$ & $5^{\prime}$-CTCTAAA $<$ AG $>$ GTCAATACTGGCCATC-3' \\
$5^{\prime} \mathrm{J}_{\mathrm{k}} 1,2,4$ & $5^{\prime}$-ACTCACGTTTGAT $<$ CT $>$ TCCA $<$ GC $>$ CTTGGTCC-3' \\
$5^{\prime} \mathrm{J}_{\mathrm{k}} 3$ & $5^{\prime}$-GTACTTACGTTTGATATCCACTTTGGTCC-3' \\
$5^{\prime} \mathrm{J}_{\mathrm{k}} 5$ & $5^{\prime}$-GCTTACGTTTAATCTCCAGTCGTGTCC-3'
\end{tabular}

The $\mathrm{V}_{\mathrm{\kappa}}$ primers hybridize to the framework region I of the respective family. $<>$ denotes a nucleotide mix at this position.

(CDR) III lengths $>9$ amino acids between IgM-only CD5 ${ }^{-}$, IgMonly $\mathrm{CD}^{+}$, and $\mathrm{IgM}^{+} \mathrm{IgD}^{+} \mathrm{CD}^{+} \mathrm{B}$ cells were assessed statistically using Fisher's exact test.

\section{Results}

$V_{\kappa}$ gene sequences of $C D 19^{+} C D 5^{+} B$ cells. After enrichment of $\kappa$ light chain-expressing PB B cells from donor HK by magnetic cell separation, single cells of the $\mathrm{CD} 19^{+} \mathrm{CD} 5^{+}$fraction, which amounted to $\sim 20 \%$ of the B cell compartment, were isolated by fluorescence-activated cell sorting (Fig. 1). Rearranged $V_{K}$ genes of individual cells were amplified from genomic DNA using a seminested PCR strategy (31). The experiment was restricted to analysis of $V_{K}$ region genes since the human immunoglobulin $\kappa$ locus is well characterized, and human $V_{\kappa}$ germline genes seem to exhibit only little polymorphism, which allows unambiguous identification of somatic

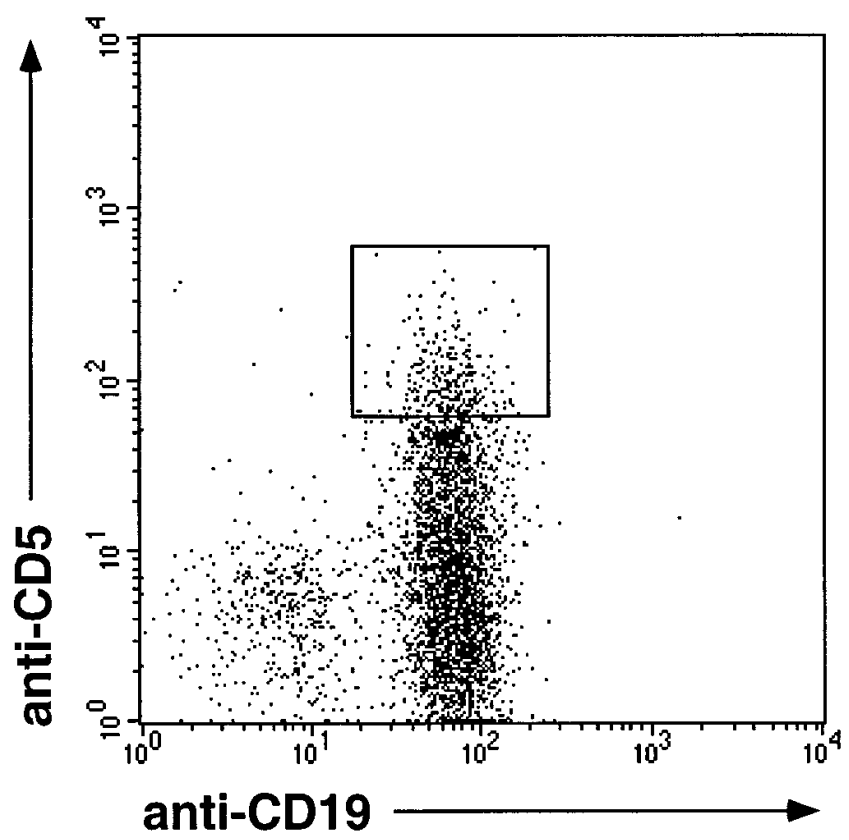

Figure 1. Flow cytometric analysis of $\kappa$-expressing B cells (after MACS enrichment) derived from PB of a 27-yr-old person (donor HK). Cells were stained with anti-CD19-FITC and anti-CD5-PE. The gate set for sorting of single $\mathrm{CD} 5^{+} \mathrm{CD} 19^{+} \mathrm{B}$ cells is indicated. mutations in rearranged $\mathrm{V}_{\kappa}$ genes $(34,35)$. Negative controls consisted of one single $\mathrm{T}$ cell, plus one reaction mixture without cells per seven B lymphocytes analyzed. None of these negative controls gave rise to a PCR product.

Of $14 \mathrm{CD}^{+} \mathrm{B}$ cells analyzed by PCR, 11 cells gave rise to a total of 14 amplificates, 12 of which were sequenced (Fig. 2). All sequences represented unique $V_{\kappa} J_{\kappa}$ joints. Cell X8 carried one in-frame and one out-of-frame rearrangement, whereas cell X9 showed only a single out-of-frame rearrangement. Cell $\mathrm{X} 12$ gave rise to two potentially functional $\mathrm{V}_{\mathrm{k}}$ region genes. This result may be explained by the fact that two cells had been sorted into the reaction tube at the isolation step. Another possibility is that one of the $\kappa$ light chains, though the gene segments had been functionally assembled, was unable to pair properly with the $\mathrm{H}$ chain expressed by the cell, and therefore an additional rearrangement occurred in the second Igк locus $(36,37)$. From each of the remaining seven cells, a single in-frame rearrangement was obtained. Whereas $V_{\kappa}$ gene rearrangements X5K4 and X8K1 showed two basepairs difference each compared to the most homologous $V_{k}$ germline genes, the other ten $\mathrm{V}_{\mathrm{K}}$ sequences turned out to be unmutated (Fig. 2 and Table II). This result indicates that the majority of human $\mathrm{CD}^{+} \mathrm{PB} B$ cells carry unmutated $\mathrm{V}_{\mathrm{K}}$ region genes. It does not, however, exclude the possibility that a small subset of mutated $\mathrm{CD}^{+} \mathrm{B}$ cells might exist in human PB.

Table II. Summary of Mutations in $V_{\kappa}$ Region Genes Amplified from $\mathrm{CDS}^{+} \mathrm{CD} 19^{+}, \mathrm{CD5}^{-} \mathrm{IgM}$-only, $C D 5^{+}$IgM-only, and $C D 5^{+} \operatorname{IgM}^{+} \operatorname{Ig} D^{+} \mathrm{PB} B$ Cells Derived from Three Donors

\begin{tabular}{lccccc}
\hline \multicolumn{1}{c}{ Cell population } & Donor & $n^{*}$ & Unmutated $^{\ddagger}$ & Range $^{\S}$ & \% Mutation \\
\hline $\mathrm{CD5}^{+}{\mathrm{CD} 19^{+}}$ & $\mathrm{HK}$ & 12 & 10 & $0-2$ & 0.1 \\
$\mathrm{CD5}^{+} \mathrm{IgM}^{+} \mathrm{IgD}^{-}$ & $\mathrm{RK}$ & 11 & 10 & $0-4$ & 0.1 \\
& $\mathrm{AB}$ & 10 & 8 & $0-4$ & 0.2 \\
$\mathrm{CD5}^{+} \mathrm{IgM}^{+} \mathrm{IgD}^{+}$ & $\mathrm{RK}$ & 11 & 11 & 0 & 0 \\
& $\mathrm{AB}$ & 13 & 13 & 0 & 0 \\
$\mathrm{CD5}^{-} \mathrm{IgM}^{+} \mathrm{IgD}^{-}$ & $\mathrm{RK}$ & 11 & 2 & $0-12$ & 2.5 \\
& $\mathrm{AB}$ & 7 & 1 & $0-16$ & 2.0 \\
\hline
\end{tabular}

*Number of $\mathrm{V}_{\mathrm{K}} \mathrm{J}_{\mathrm{K}}$ rearrangements analyzed; ${ }^{\ddagger}$ number of unmutated $\mathrm{V}_{\mathrm{K}} \mathrm{J}_{\mathrm{K}}$ rearrangements; ${ }^{\S}$ range of mutations per gene. "Mutation frequencies were calculated by considering the nucleotide differences in the $V_{K}$ region genes relative to the corresponding $V_{\kappa}$ and $J_{\kappa}$ germline genes, except for the non-germline-encoded nucleotides at the $\mathrm{V}_{\mathrm{K}} \mathrm{J}_{\mathrm{K}}$ junctions. 


\begin{tabular}{|c|c|c|c|c|c|c|c|c|c|c|c|c|c|c|}
\hline & & \multirow[t]{2}{*}{$\mathbf{v}_{k}$} & \multicolumn{3}{|c|}{$3^{\prime} v_{k}$} & \multicolumn{3}{|c|}{$v_{k}-J_{k}$ junction } & \multicolumn{3}{|r|}{$5^{\prime} \mathrm{J}_{k}$} & \multirow[t]{2}{*}{$\mathbf{J}_{\mathbf{k}}$} & \multirow[t]{2}{*}{ in frame } & \multirow[t]{2}{*}{ bp diff } \\
\hline & & & 93 & 94 & 95 & $95 \mathrm{~A}$ & $\mathbf{N}$ & 96 & 97 & 98 & 99 & & & \\
\hline & $\times 1 K 4$ & B3 & AGT & ACT & $c C$ & & & G TGG & $A C G$ & TTC & GGC & 1 & + & 0 \\
\hline & $\mathrm{X} 2 \mathrm{~K} 1$ & LFVK431 & AGT & TAC & $\mathrm{CCT}$ & & CTG & & ACT & TTC & GGC & 4* & + & 0 \\
\hline & $\times 5 K 4$ & B3 & AGT & $\mathrm{ACT}$ & CCT & & & TGG & $A C G$ & TTC & GGC & 1 & + & 2 \\
\hline & $\mathrm{x} 6 \mathrm{~K} 3$ & L6 & AAC & TGG & $\mathrm{CCT}$ & $\mathrm{CC}$ & & G CTC & ACT & TTC & & 4 & + & 0 \\
\hline & $\times 8 \times 1$ & L5 & AGT & TTC & $\mathrm{CCT}$ & $\mathrm{C}$ & & $A C$ & ACT & TTT & $G G C$ & 2 & + & 2 \\
\hline \multirow[t]{7}{*}{$\cos ^{+} \cos 19^{+}$} & $\times 8 K 4$ & $\mathrm{~B} 3$ & AGT & ACT & $\mathrm{CC}$ & & C & GCT & CAC & $\mathrm{TTT}$ & CGG & 4 & - & 0 \\
\hline & $\times 9 \mathrm{~K} 2$ & A17 & CAC & TGG & $\mathrm{CCT}$ & $\mathrm{CCC}$ & & TCN & $\mathrm{CTT}$ & TCG & & 4* & - & 0 \\
\hline & $\times 10 K 2$ & A3 & CAA & ACT & $\mathrm{CCT}$ & $\mathrm{C}$ & $T$ & A TTC & ACT & TTC & $G G C$ & 3 & + & 0 \\
\hline & $\mathrm{X} 11 \mathrm{~K} 4$ & B3 & AGT & ACT & $\mathrm{CC}$ & & & G ATC & $A C C$ & TTC & GGC & 5 & + & 0 \\
\hline & $\mathrm{X} 12 \mathrm{~K} 1$ & L12A & AGT & TAT & TCT & $C$ & & GG & $A C G$ & TTC & GGC & 1 & + & 0 \\
\hline & $\times 12 K 3$ & L2 & AAC & TGG & $\mathrm{CCT}$ & $\mathrm{CC}$ & $A G$ & GG & $A C G$ & TTC & GGC & 1 & + & 0 \\
\hline & $\mathrm{X} 13 \mathrm{~K} 2$ & $A 3$ & CAA & ACT & $\mathrm{CCT}$ & $C$ & $A G$ & & ACT & TTC & GGC & $3^{*}$ & + & 0 \\
\hline
\end{tabular}

Figure 2. Nucleotide sequences of $\mathrm{V}_{\kappa} \mathrm{J}_{\kappa}$ junctions amplified from $\mathrm{CD} 5^{+} \mathrm{CD} 19^{+} \mathrm{PB}$ B cells by single-cell PCR. Sequences are designated by an $\mathrm{X}$ and a sample number of the cell, followed by the corresponding $V_{k}$ family to which the sequence was assigned. Shown are the $3^{\prime}$ end of the respective $V_{\kappa}$ gene, N-region nucleotides $(N)$, and the $5^{\prime}$ end of $J_{\kappa}$. In addition, the corresponding $V_{\kappa}$ and $J_{\kappa}$ germline genes are indicated. $J_{\kappa}$ genes identified by $\mathrm{J}_{\kappa}$ typing (see Methods) are denoted by *. The sum of nucleotide differences relative to the corresponding germline genes is shown in the right column. Codons are numbered according to Kabat et al. (74). Full-length sequences are available from EMBL/GenBank under accession nos. Z98605-Z98679.

$V_{\kappa}$ gene sequences of $\operatorname{Ig} M^{+} \operatorname{Ig} D^{+}$and $\operatorname{Ig} M^{+} \operatorname{Ig} D^{-} C D 5$ expressing $B$ cells. The expression of mutated $\mathrm{V}$ genes in human B lymphocytes is mainly restricted to isotype-switched and IgM-only $\left(\operatorname{IgM}^{+} \operatorname{IgD}{ }^{-}\right)$B cells $(15-17,31)$. These two B
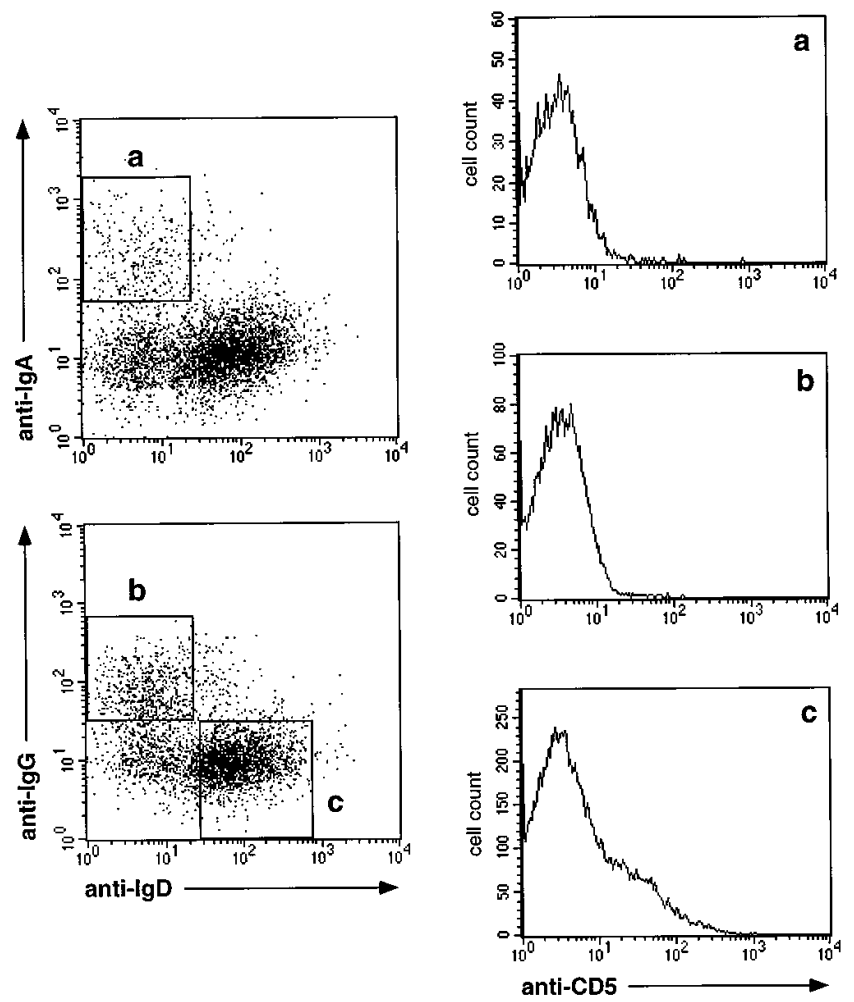

Figure 3. Peripheral blood. Flow cytometric analysis of MACSenriched $\mathrm{CD} 19^{+} \mathrm{PB}$ B cells derived from a healthy adult person. Cells were stained with anti-CD5-PE, anti-IgD-CyChrome, and either (left top) anti-IgA-FITC or (left bottom) anti-IgG-FITC. (Left) Windows were set around $(a)$ the $\mathrm{IgA}^{+},(b)$ the $\mathrm{IgG}^{+}$, and $(c)$ the $\mathrm{IgD}^{+}$populations. (Right) CD5-expression of (top) $\mathrm{IgA}^{+}$, (middle) $\mathrm{IgG}^{+}$, and (bottom) $\mathrm{IgD}^{+}$cells. cell subsets represent $\sim 15 \%$ and $10 \%$ of human PB B cells, respectively, whereas naive $\operatorname{IgM}^{+} \operatorname{IgD}^{+} \mathrm{B}$ cells usually comprise more than $70 \%$ of all PB B lymphocytes $(15,31,38,39)$. Consequently, the question arose as to whether $\mathrm{CD}^{+} \mathrm{B}$ cells
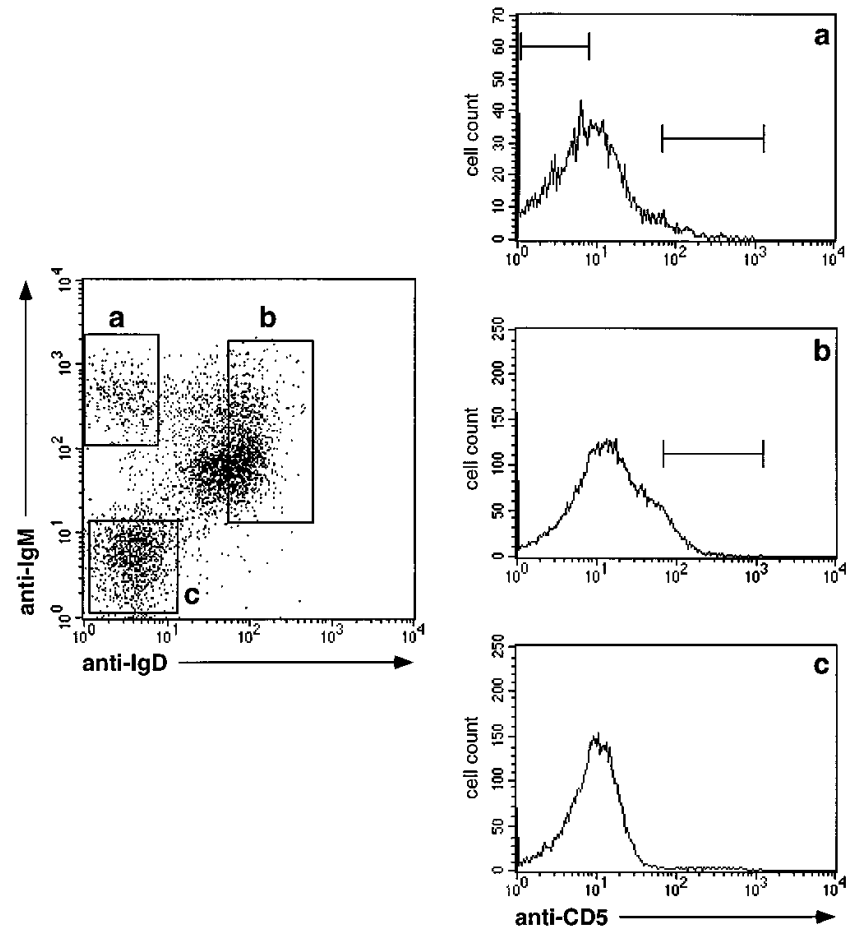

Figure 4. Peripheral blood. Flow cytometric analysis of $\kappa$-expressing B cells (after MACS-enrichment) derived from PB of a 32-yr-old person (donor RK). Cells were stained with anti-IgM-PE, anti-IgDCyChrome, and anti-CD5-FITC. (Left) Windows were set around (a) the $\operatorname{IgM}^{+} \operatorname{IgD}^{-}$(IgM-only), (b) the $\operatorname{IgM}^{+} \operatorname{IgD}{ }^{+}$, and $(c)$ the $\operatorname{IgM}^{-} \operatorname{IgD}^{-}$ (i.e., predominantly isotype-switched B cells) fractions. (Right) CD5expression of (top) $\mathrm{IgM}^{+} \mathrm{IgD}^{-}$, (middle) $\mathrm{IgM}^{+} \mathrm{IgD}^{+}$, and (bottom) $\mathrm{IgM}^{-} \mathrm{IgD}^{-}$cells. Indicated are the gates set for sorting of single $\mathrm{CD}^{-}{ }^{-} \operatorname{IgM}^{+} \operatorname{IgD}^{-}, \mathrm{CD}^{+} \operatorname{IgM}^{+} \operatorname{IgD}^{-}$, and $\mathrm{CD}^{+} \operatorname{IgM}^{+} \operatorname{IgD}^{+}$cells. 
A

$\mathrm{CD}^{-}$

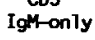

$\operatorname{Ig}^{\operatorname{CD}^{+}} \operatorname{Ig}^{+}$

$\underset{\text { Ig }}{\operatorname{CDS}^{+}}$

$\mathrm{CD}^{-}$

Igttonly

$\cos ^{\circ}$

Igr-only

$\mathrm{CD5}^{+}$

B

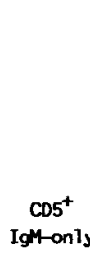

$v_{k}$

$3^{\prime} v_{k}$

$\begin{array}{llll}93 & 94 & 95 & 95 \mathrm{~A}\end{array}$

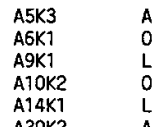

$\begin{array}{ll}\text { A } 14 K 1 & \text { L12A } \\ \text { A 30K2 } & \text { A17 }\end{array}$

A30K2

AZ2K2

AZ5K3

AZ5K3
AZ6K2 2

AZ7K2

B7K2 $\quad$ A17

$\mathrm{B15K3}$

B16K

B24K1 018

B25K3

B42K

B44K3 L2

$\begin{array}{ll}\text { BZ1K1 } & \text { L12A } \\ \text { BZ2K1 } & \text { L23 }\end{array}$

BZ2K2

C3K1

C4K1
C4K2

C6K1

C6K2

C8K1

C10K3
C15K1

C31K2
C33K2

CZ1K3

$\mathrm{Ig}^{+} \mathrm{IgD}^{+}$

$v_{k}$

$v_{k}$

$3^{\prime} v_{k}$

AGT CTC $\propto C$

AGT TTC CC

AGT $T$

CAC TGG $C C$

CAA ACT CC

AGT TAC CCT

AAC TGG CCT

CAC CTT C

CAC ACT CC

CAC TGG $C$

AGC TCA CC

AAT CTC CC

AAT ACC CCT

AGC TCA CC

AGT ACC CCT C

AAC TGG CCT CC

AGT TAT T

AGT TTC CCT $C$

AGT ACC CC

CAA ACT CC

AGT ACC CCT

CAC TGG CC

AGT ACC CC

AGC TCA CCT

AGT TAC CC

CAC TGG

\section{$\begin{array}{llll}93 & 94 & 95 & 95 \mathrm{~A}\end{array}$}

D24K3

AAC TGG CC

E3K4

E5K3

B3 AGT ACT C

A11A AGG TCA CCT

A17 CAC TGG CCT CC

AAC TGG CCT CC

AGC TCA C

AGC TCA CC

AAT CTC CCT $\subset$

AGT ACT CCT CC

AGT TAT

AGC TCA

AGC TCA CCT $\triangle C$

AGT ACT CC

AGT TAT TCT

AAC TGG CCT CC

AAT CTC CC
B20K2 A3

AGT ACC CC

CAA ACT CC GTA CC

AGC TCA CCT C TC

$v_{k}-J_{k}$ junction

$5^{\prime} \mathbf{J}_{k}$

$\mathbf{J}_{k}$

in frame

bp diff.

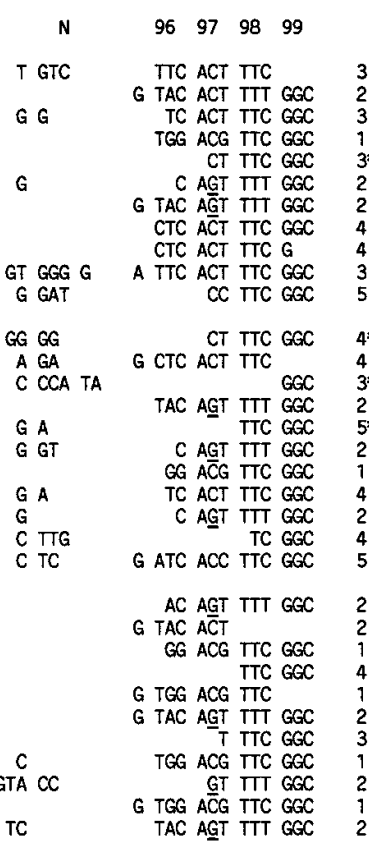

3
2
3
1
$3^{*}$
2
2
4
4
3
5
$4^{*}$
4
$3^{*}$
2
$5^{*}$
2
1
4
2
4
5
2
2
1
4
1
2
3
1
2
1
2

$\begin{array}{lr}+ & 10 \\ + & 10 \\ + & 7 \\ + & 2 \\ + & 12 \\ - & 7 \\ + & 10 \\ + & 8 \\ + & 7 \\ - & 0 \\ - & 0 \\ & \\ + & 0 \\ + & 0 \\ - & 0 \\ + & 4 \\ - & 0 \\ + & 0 \\ + & 0 \\ + & 0 \\ + & 0 \\ - & 0 \\ + & 0 \\ + & 0 \\ + & 0 \\ + & 0 \\ + & 0 \\ + & 0 \\ + & 0 \\ + & 0 \\ + & 0 \\ + & 0 \\ + & 0 \\ + & 0\end{array}$

$V_{k}-J_{k}$ junction

$5^{\prime} J_{k}$

$\mathfrak{J}_{\mathbf{k}}$

in frame

bp diff.

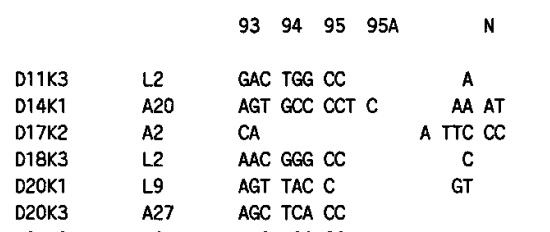

$\begin{array}{llll}96 & 97 & 98 & 99\end{array}$

TC
$A C G G A$
$G G$

ACG TTC GGC A CTT TCG

C ACT TTC

TAC ACT TTT GGC

GCT CAC TIT CGG

G ATC ACC TTC GGC

G CTC ACT TTC

GTA CAC TTT TGG G CTC ACT TTC

CIT TTG GCC
TGG ACG TTC GGC

$G$ ACG TTC

G GA TGG ACG TTC $G$

$G$ G TGG ACG TTC GGC

$G A G$

C ACT TTC
TCG

TGG ACG TTC GGC

G TAC ACT TIT GGC

AGT TAT

AGT TAC CCT C

AAC TGG CCT CC

AGT ACC CCT

AAC TGG CCT CC
CCC AC G TGG ACG TTC GGC

TCT

C TC

TGG ACG TTC GGC

G ATC ACC TTC GGC

C ACC TTC GGC

TCA CTT TCG GC

G ACG TTC GG

C CCT

TT TT

GG

GC TCA CTT TOG

TC G ATC ACC TTC GGC

$G$ GA G CTC ACT TTC GG
ACT TTC GG
G CTC ACT TTC GG

F24K1
F25K3

L6

$\begin{array}{llr}1 & + & 5 \\ 4^{*} & - & 0 \\ 4^{*} & + & 3 \\ 2 & + & 16 \\ 4 & - & 2 \\ 5 & + & 2 \\ 4 & + & 7\end{array}$

$2-0$

0

0

4
0

0

0

1
0
0

0

0

0

0

0

0

0

0

0
Figure 5. Nucleotide sequences of $V_{k} J_{K}$ junctions amplified from CD5 ${ }^{-}$IgM-only, $\mathrm{CD}^{+}{ }^{+} \mathrm{IgM}$-only, and $\mathrm{CD}^{+} \operatorname{IgM}^{+} \operatorname{IgD}^{+}$PB B cells by single-cell PCR. ( $A$ ) Donor RK; $(B)$ donor AB. Sequences are designated by one or two uppercase letters and a sample number of the cell, followed by the corresponding $\mathrm{V}_{\mathrm{k}}$ family to which the sequence was assigned. Shown are the $3^{\prime}$ end of the respective $\mathrm{V}_{\mathrm{k}}$ gene, $\mathrm{N}$-region nucleotides $(N)$, and the $5^{\prime}$ end of $\mathbf{J}_{\kappa}$. The corresponding $\mathrm{V}_{\mathrm{K}}$ and $\mathrm{J}_{\mathrm{K}}$ germline genes are indicated. The sum of nucleotide differences relative to the corresponding germline genes is shown in the right column. The $\mathrm{C}$ to $\mathrm{G}$ nucleotide exchange at position two of codon 97 of the novel polymorphic $\mathrm{J}_{\mathrm{K}} 2$ gene segment (donor $\mathrm{RK}$ ) is underlined. Full-length sequences are available from EMBL/ GenBank under accession nos. Z98605-Z98679. * $\mathrm{J}_{\kappa}$ genes identified by $\mathrm{J}_{\mathrm{K}}$ typing (see Methods); ${ }^{\S}$ pseudogene; ${ }^{\text {thomology to germ- }}$ line gene $\mathrm{A} 27$ of sequence $\mathrm{F} 22 \mathrm{~K} 3$ ends at position one of codon 90 . occur among class-switched and/or IgM-only B cells, and, if this was the case, whether those CD5-positive B lymphocytes harbor mutated $\mathrm{V}$ genes. Although class-switched cells are thought to be negative for CD5 expression, in the literature one finds surprisingly little data on this subject (40). To clarify this matter, MACS-enriched CD $19^{+} \mathrm{PB}$ B cells derived from seven healthy adult donors were stained with anti-IgD and anti-CD5, and with either anti-IgA or anti-IgG. FACScan analysis revealed in all cases that CD5-expressing cells were barely detectable (i.e., $<1 \%$ ) among isotype-switched $\mathrm{B}$ cells (Fig. 3). On the other hand, we reported in a previous study on a small fraction of $\mathrm{CD}^{+} \mathrm{B}$ lymphocytes within the PB IgMonly compartment (31). This result was confirmed by flow-cytometric analysis of PB B cells (from donors RK and AB) that were enriched by magnetic cell separation and stained with anti-IgM, anti-IgD, and anti-CD5 (Fig. 4). The fraction of 
$\mathrm{CD}^{+} \mathrm{B}$ cells among the IgM-only subset accounted for $\sim 10 \%$ each, whereas the fraction of $\mathrm{CD}^{+} \mathrm{B}$ cells among the $\operatorname{IgM}^{+} \mathrm{IgD}^{+}$compartment amounted to $\sim 20 \%$ in both cases.

To determine the level of somatic mutation within rearranged $\mathrm{V}_{\mathrm{K}}$ genes, single $\kappa$-positive $\mathrm{B}$ cells of both donors were isolated from the $\mathrm{CD}^{+} \mathrm{IgM}^{+} \mathrm{IgD}^{+}$, the $\mathrm{CD}^{+} \mathrm{IgM}^{+} \mathrm{IgD}^{-}$, and, as a control, from the $\mathrm{CD5}^{-} \mathrm{IgM}^{+} \mathrm{IgD}^{-}$subset. From donor $\mathrm{RK}$, single cells of all three fractions were isolated twice in two separate experiments. Single-cell PCR and sequencing were performed as described above. Taking both donors together, a total of 106 cells were analyzed by PCR. 52 cells gave rise to a single, and 10 cells to two distinct PCR products. 63 amplificates from 55 cells were sequenced, all of which represented unique $V_{\kappa} J_{\kappa}$ rearrangements (Fig. 5). Eleven cells showed a single out-of-frame rearrangement, whereas six cells carried both a productive and a nonproductive $\mathrm{V}_{\mathrm{K}} \mathrm{J}_{\mathrm{K}}$ joint. Again, two cells (C6 and F23) gave rise to two distinct in-frame rearrangements each. The remaining 36 cells revealed a single potentially functional $\mathrm{V}_{\mathrm{K}}$ region gene each.

15 out of 18 rearrangements of the $\mathrm{CD}^{-} \mathrm{IgM}$-only compartment turned out to be mutated (range: 2-16 mutations, Figs. 5 and 6 and Table II). Interestingly, the three unmutated sequences represented out-of-frame $V_{\kappa} J_{\kappa}$ joints (Fig. 5). These three genes may be derived from cells that carry somatic mutations in the heavy chain and functional light chain genes: in some $\kappa$ light chain-expressing B cells, the second (presumably nonfunctional) rearranged $\kappa$ allele is inactivated by deletion of the $C_{\kappa}$ gene and the $\kappa$ enhancers, leaving the $V_{\kappa} J_{\kappa}$ joint untouched (41). This deletion most likely abolishes somatic mutation in the respective $V_{K} J_{\kappa}$ joint $(33,42)$. The frequency of somatic mutation of $\mathrm{CD}^{-}$IgM-only $\mathrm{PB} \mathrm{B}$ lymphocytes was calculated to be $2.5 \%$ for donor $\mathrm{RK}$, and $2.0 \%$ for donor $\mathrm{AB}$ (Table II). Both values are in a similar range to mutation frequencies observed for IgM-only PB B cells in previous studies $(15,31)$. In contrast, only 3 out of 21 rearrangements of the $\mathrm{CD}^{+}$IgM-only subset harbored somatic mutations (1, 4, and 4 nucleotide exchanges), whereas the other 18 sequences were identical to the corresponding $\mathrm{V}_{\mathrm{K}}$ and $\mathrm{J}_{\mathrm{K}}$ germline genes (Figs. 5 and 6 and Table II). In addition, among 24 rearrangements obtained from $\mathrm{CD}^{+} \mathrm{IgM}^{+} \mathrm{IgD}^{+} \mathrm{PB}$ B cells, not a single point mutation was found (Figs. 5 and 6 and Table II).

Evidence for a novel polymorphic $\mathrm{J}_{\kappa} 2$ gene segment. The $\mathrm{J}_{\mathrm{k}} 2$ gene segment was found to be rearranged in eleven clonally independent $\mathrm{V}_{\mathrm{K}}$ region genes obtained from cells of donor RK
CD5- IgM-only

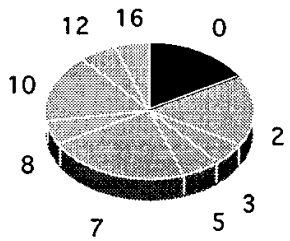

$\mathrm{n}=18$
CD5+ IgM-only

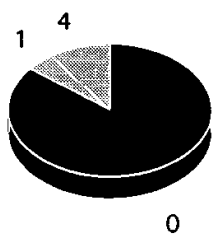

$n=21$

\section{$\mathrm{CD} 5+\lg \mathrm{M}+\lg \mathrm{D}+$}

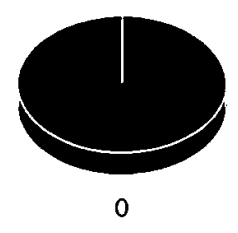

$n=24$
Figure 6. Distribution of $\mathrm{V}_{\mathrm{k}}$ region genes with respect to the number of mutations they carry. Each part depicts the proportion of sequences with mutations as specified. Sequences of donors RK and $\mathrm{AB}$ are summarized. $(n)$ Total number of sequences of each population.
(Fig. 5 A). Position two of codon 97 of the respective rearranged $\mathrm{J}_{\mathrm{k}} 2$ genes differed from the published $\mathrm{J}_{\mathrm{k}} 2$ germline gene (43) by a $\mathrm{C}$ to $\mathrm{G}$ nucleotide exchange in nine of these rearrangements. Since six of those $\mathrm{V}$ region genes carried no mutation in the rest of their sequence, it is unlikely that the $\mathrm{C}$ to $\mathrm{G}$ exchanges represent somatic mutations. The result rather suggests that donor RK is heterozygous for a previously unidentified polymorphic $\mathrm{J}_{\mathrm{K}} 2$ gene which replaces a threonine (encoded by ACT) by a serine (AGT) at the last position of the CDRIII. A search in the European Molecular Biology Laboratories database (release 95) revealed that a $\mathrm{J}_{\mathrm{K}} 2$ gene with AGT at codon 97 was previously sequenced from three other individuals, although this was not identified as a polymorphism in those studies (44-46). Thus, we identified a novel, albeit rare $\mathrm{J}_{\mathrm{K}} 2$ gene polymorphism.

$V_{\kappa}$ gene usage of $C D 5^{+} B$ cells. We obtained 43 potentially functional $\mathrm{V}_{\kappa} \mathrm{J}_{\kappa}$ joints from $\mathrm{CD}^{+} \mathrm{B}$ cells. The sequences could be assigned to a total of 16 different $V_{k}$ germline genes of the $V_{\kappa}$ gene families $1,2,3$, and 4 . Nine sequences showed highest homology to the $V_{k} 3$ gene $A 27$, five sequences each to the single $\mathrm{V}_{\mathrm{k}} 4(\mathrm{~B} 3)$ gene and the A3/A19 $\left(\mathrm{V}_{\mathrm{k}} 2\right)$ gene, and four sequences to $\mathrm{O} 2 / \mathrm{O} 12\left(\mathrm{~V}_{\mathrm{k}} 1\right)$. Three sequences each could be assigned to L12A $\left(\mathrm{V}_{\mathrm{k}} 1\right)$, L2 $\left(\mathrm{V}_{\mathrm{k}} 3\right)$, and L6 $\left(\mathrm{V}_{\mathrm{k}} 3\right)$. Nine $\mathrm{V}_{\mathrm{k}}$ germline genes were found to be rearranged either once or twice (Figs. 2 and 5). The $\mathrm{V}_{\mathrm{k}}$ genes that have been used frequently by $\mathrm{CD}^{+} \mathrm{B}$ cells in this study, in particular A27, were also found to be overrepresented in compilations of rearranged $\mathrm{V}_{\mathrm{K}}$ sequences, the majority of which were derived from conventional B cells $(35,47)$. Thus, it appears that human $\mathrm{CD}^{+} \mathrm{PB} \mathrm{B}$ cells do not differ considerably from conventional $B$ cells with regard to $V_{\kappa}$ gene usage.

$N$-region additions at $V_{\kappa} J_{\kappa}$ junctions of $C D 5^{+} B$ cells. A hallmark of murine B cells developing early in ontogeny, a substantial fraction of which belongs to the CD5-expressing subset $(1,48)$, is the rare occurrence of non-germline-encoded nucleotides at the $\mathrm{V}_{\mathrm{H}} \mathrm{D}_{\mathrm{H}} \mathrm{J}_{\mathrm{H}}$ junctions $(49,50)$. On the other hand, $\mathrm{N}$-region additions have frequently been detected in $\mathrm{CD}^{+}$ $\mathrm{B}$ cells obtained from adult mice, even though less frequently than in conventional B cells (62\% versus $93 \%)$ (49-51).

In contrast, $\mathrm{N}$ sequences are a common feature of human $\mathrm{B}$ lymphocytes already in the fetus, and they appear to be consistently present at $\mathrm{V}_{\mathrm{H}} \mathrm{D}_{\mathrm{H}} \mathrm{J}_{\mathrm{H}}$ junctions of $\mathrm{B}$ cells in the adult (52, 53). Moreover, IgH CDRIII sequences derived from $\mathrm{CD}^{+}$ and $\mathrm{CD}^{-}$human cord blood $\mathrm{B}$ cells revealed no significant difference with respect to the frequency of N-region additions (54). In our collection of $57 \mathrm{~V}_{\mathrm{\kappa}}$ gene rearrangements amplified from $\mathrm{CD}^{+} \mathrm{B}$ cells of three adult donors, 34 contained nongermline-encoded nucleotides at their $V_{\kappa} J_{\kappa}$ junctions $(60 \%)$, whereas $\mathrm{N}$ sequences were found at 10 out of $18 \mathrm{~V}_{\mathrm{K}} \mathrm{J}_{\mathrm{K}}$ junctions derived from $\mathrm{CD}^{-} \mathrm{B}$ cells (56\%) (Figs. 2 and 5). These data, therefore, support the notion that $\mathrm{N}$-region additions occur frequently in human $\mathrm{CD}^{+} \mathrm{B}$ cells, and that the frequency, unlike in the mouse, does not differ from that of conventional B cells.

CDRIII lengths of potentially functional $V_{\kappa}$ region genes. Comparison of the CDRIII lengths of potentially functional $\mathrm{V}_{\mathrm{K}}$ region genes demonstrated distinct patterns between $\mathrm{CD5}^{-}$ and $\mathrm{CD}^{+} \mathrm{B}$ cells: whereas none of the 13 rearrangements obtained from $\mathrm{CD}^{-} \mathrm{IgM}$-only B cells revealed CDRIIIs exceeding 9 amino acids, those CDRIIIs were found in 7 of 15 rearrangements (10 codons each) of the $\mathrm{CD}^{+} \mathrm{IgM}$-only and in 7 of 18 rearrangements ( 6 with 10 and one with 11 codons) of the 
$\mathrm{CD}^{+} \mathrm{IgM}^{+} \mathrm{IgD}^{+}$subpopulation (Fig. 5). The difference between the $\mathrm{CD}^{-}$subset on the one hand, and the $\mathrm{CD}^{+} \mathrm{IgM}$ only as well as the $\mathrm{CD}^{+} \mathrm{IgM}^{+} \mathrm{IgD}^{+}$subset on the other, was statistically significant $(P=0.005$ and $P=0.012$, respectively). In contrast, the two $\mathrm{CD}^{+} \mathrm{B}$ cell fractions did not differ significantly from each other $(P=0.461)$.

Since it has been suggested that CD5-expressing B cells are involved in autoimmune diseases, particularly in rheumatoid arthritis $(1,5-7)$, it is interesting to note that Bridges et al. recently reported on increased proportions of $V_{\mathrm{K}}$ transcripts with unusually long CDRIIIs amplified from synovia and PB of patients with rheumatoid arthritis as compared to healthy individuals (55). This overrepresentation, however, was rather due to an increase in $\mathrm{V}_{\mathrm{K}} \mathrm{J}_{\mathrm{K}}$ joints containing CDRIIIs of 11 amino acids, than to an increase in those with CDRIIIs of 10 amino acids, the latter being overrepresented in the $\mathrm{CD}^{+}$subsets of this study. Thus, the relationship between CD5-positive B cells carrying $\mathrm{V}_{\mathrm{K}}$ region genes with extended CDRIII lengths and $\mathrm{B}$ cells expressing $V_{K}$ region genes with long CDRIIIs in patients suffering from rheumatoid arthritis remains to be clarified.

Analysis of tonsillar $B$ cell subsets with regard to CD5 expression. To determine whether the distribution of CD5 on $\mathrm{B}$ cell subsets derived from secondary lymphoid organs resembles that seen in the PB, we analyzed tonsillar B cells for expression of CD5 on IgM-expressing, as well as on isotypeswitched B lymphocytes. Besides naive and memory B cells, the tonsil contains a large fraction of GC B cells (17). These cells are known to be CD5-negative (56). To avoid masking in the flow cytometric analysis of tonsillar memory and naive B cells for CD5 expression by the numerous GC B cells, we depleted the latter, and, in addition, T cells, by magnetic cell separation. Concerning the pattern of $\mathrm{IgM}$ and $\mathrm{IgD}$ expression on the enriched cells, we were surprised to find only two of seven tonsils showing a clearly discernible IgM-only subpopulation. Whereas most tonsils were derived from children or young adults (ages 5-19), these two tonsils were from donors over 30 years old, suggesting that IgM-expressing memory cells in this tissue accumulate with age. In one of these cases, expression of $\mathrm{CD} 5$ on $\mathrm{IgM}^{+} \mathrm{IgD}^{+}$on the one hand, and IgM-only cells on the other, resembled that seen on their counterparts in the PB (data not shown). In the other case, the sample size was too small to determine the fraction of CD5-positive IgM-only $\mathrm{B}$ cells. The $\mathrm{IgM}^{+} \mathrm{IgD}^{+}$cells of the remaining tonsils, like $\mathrm{IgM}^{+} \mathrm{IgD}^{+} \mathrm{PB} \mathrm{B}$ cells, comprised $\sim 20 \% \mathrm{CD}^{+}$cells (data not shown). Additionally, fractions enriched for non-GC B cells from three tonsils were analyzed for the CD5 expression on class-switched B cells. Fig. 7 shows that, whereas a sizeable proportion of $\mathrm{IgD}$-positive $\mathrm{B}$ cells expressed CD5, few if any CD5-positive cells could be detected among $\mathrm{IgG}^{+}$and $\mathrm{IgA}^{+} \mathrm{B}$ cells. Thus, at least in the case of the tonsil, the expression pattern of CD5 on B cell subsets of secondary lymphoid organs mirrors that seen on the corresponding PB B lymphocyte subsets (Figs. 3, 4, and 7).

\section{Discussion}

Previous investigations suggested that $C D 5^{+} B$ cells in healthy individuals regularly acquire somatic mutations. In three RNA-based studies, somatic mutations were found in 12/ 16 (29), 16/23 (30), and 5/8 (16) V gene transcripts amplified from populations of $\mathrm{CD}^{+} \mathrm{B}$ cells isolated by flow cytometry. In yet another RNA-based study, the ratio of mutated to un-
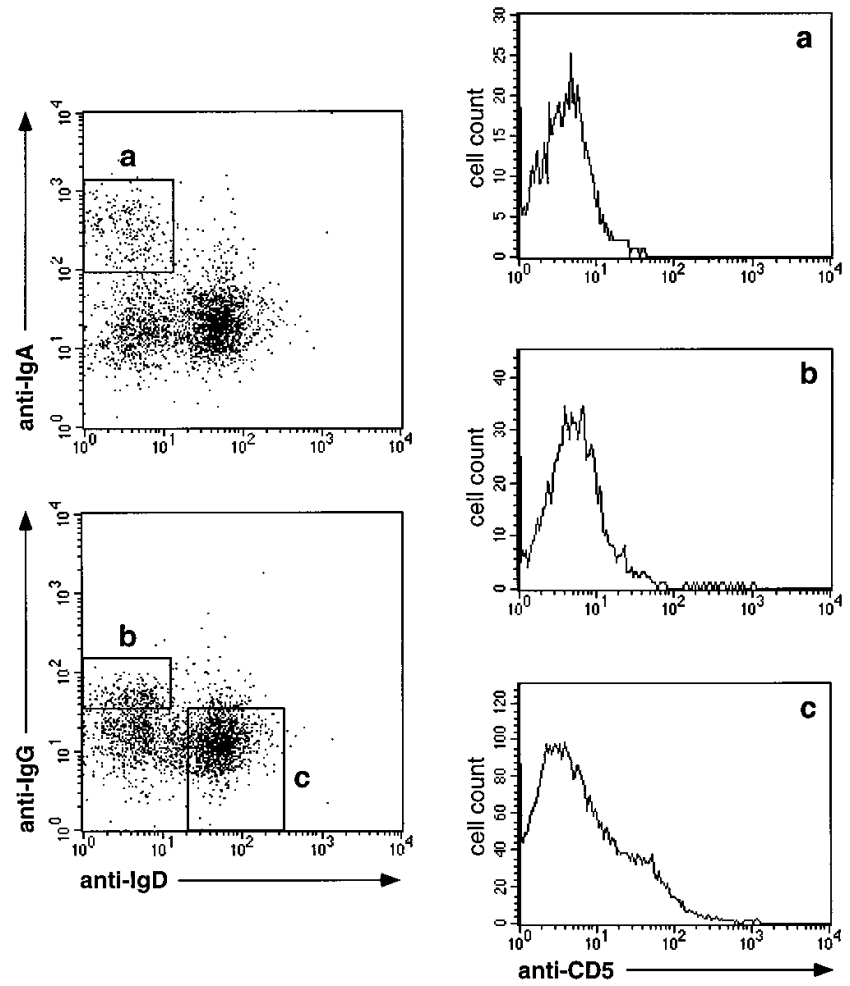

Figure 7. Tonsil. Flow cytometric analysis of MACS-enriched tonsillar non-GC B cells (naive and memory B cells) derived from a 32-yr-old adult. Cells were stained with anti-CD5-PE, anti-IgDCyChrome and either (left top) anti-IgA-FITC or (left bottom) antiIgG-FITC. Windows were set around $(a)$ the $\operatorname{IgA}^{+},(b)$ the $\mathrm{IgG}^{+}$, and (c) the $\mathrm{IgD}^{+}$populations. (Right) $\mathrm{CD} 5$ expression of (top) $\operatorname{Ig} \mathrm{A}^{+}$, (middle) $\mathrm{IgG}^{+}$, and (bottom) $\mathrm{IgD}^{+}$cells.

mutated V genes (3/9) was lower (46). Moreover, 16 cell lines generated by EBV transformation of $\mathrm{CD}^{+} \mathrm{B}$ cells from healthy adult donors have been described in the literature (25, 57-59). Among those lines, 12 have been reported to be mutated. Collectively, these studies suggested that the majority of $\mathrm{CD}^{+} \mathrm{B}$ cells in healthy humans express somatically mutated $\mathrm{V}$ genes.

Despite the conformity of these data, the following observations prompted us to reinvestigate $\mathrm{V}$ genes of human $\mathrm{CD}^{+}$ $\mathrm{B}$ cells for somatic mutation: first, the finding that most $\mathrm{CD}^{+}$ $\mathrm{B}$ cells are found among $\operatorname{IgM}^{+} \mathrm{IgD}^{+} \mathrm{B}$ lymphocytes, the vast majority of which carry unmutated $\mathrm{V}$ region genes $(15-17,31)$, implies that most $\mathrm{CD}^{+} \mathrm{B}$ cells express unmutated $\mathrm{V}$ region genes. Second, we recently observed that IgM-only and classswitched B cells harbor elevated levels of mRNA for $\kappa$ light chains when compared with $\operatorname{IgM}^{+} \operatorname{IgD}^{+}$naive B cells (31). Since IgM-only as well as class-switched B cells carry somatically mutated $\mathrm{V}$ genes $(15,16,31)$, the presence of such cells in a given sample will bias population-based studies of $\mathrm{V}$ gene transcripts towards mutated sequences. This consideration is particularly important in analyses of $\mathrm{CD}^{+} \mathrm{B}$ cells: since CD5 is expressed on B cells only weakly, the populations of conventional and $\mathrm{CD}^{+} \mathrm{B}$ cells overlap in flow cytometric analyses (see Figs. 1, 3, 4, and 7) $(2,3,16,29,30)$. Thus, sorted CD5 ${ }^{+}$ populations are likely to be contaminated by conventional $\mathrm{B}$ cells, $\sim 20-30 \%$ of which are IgM-only or class-switched cells. We therefore conclude that RNA-based population studies do 
not represent a suitable approach to determine the frequency of $\mathrm{CD}^{+} \mathrm{B}$ cells harboring mutated $\mathrm{V}$ genes.

Furthermore, the collection of EBV lines derived from $\mathrm{CD}^{+} \mathrm{B}$ cells is clearly not representative of the $\mathrm{CD}^{+} \mathrm{B}$ cell population; two of the lines harboring mutated $\mathrm{V}$ genes express isotypes other than $\operatorname{IgM}(57)$, which is atypical for $\mathrm{CD}^{+}$ B cells, as we and others have shown (Figs. 3 and 7) (40,60). In addition, in the work of Schutte et al. (59), the two lines analyzed were the only ones that expressed CD5 among 500 lines established from adult $\mathrm{PB}$. This underrepresentation of CD5expressing EBV lines is not surprising, since sorted $\mathrm{CD}^{+} \mathrm{B}$ cells usually lose CD5 expression upon EBV immortalization $(59,61)$. Under these circumstances, the two CD5-positive lines can hardly be regarded as being representative of $\mathrm{CD}^{+}$ B cells. Nevertheless, analyses of the EBV lines indicate that some $\mathrm{CD}^{+} \mathrm{B}$ cells carrying somatic mutations can be found in healthy adults, although their frequency cannot be reliably determined from those investigations $(25,57-59)$.

The vast majority of $C D 5^{+} P B B$ cells in healthy humans carry unmutated $V$ region genes. In this study, CD5-expressing PB B cells derived from healthy adults were analyzed for the level of somatic mutation in rearranged $V_{\kappa}$ genes by single-cell PCR. This approach has several advantages when compared with the analysis of cell lines or cDNA-libraries generated from cell populations (62); a single-cell experiment is obviously not biased by varying transcript levels or by preferential EBV transformation of particular subsets of cells. By analyzing single cells, the frequency of B cells harboring somatically mutated $\mathrm{V}$ region genes within a B cell subset can be reliably determined. Furthermore, single-cell PCR allows unambiguous identification of somatic mutations in contrast to cell population analyses that involve cloning of PCR products. Amplificates obtained from single cells can be sequenced directly without being cloned, and therefore sequence errors due to misincorporation by Taq DNA polymerase are negligible.

In a first experiment, $\mathrm{V}_{\mathrm{\kappa}}$ region genes of single $\mathrm{CD}^{+}$ CD19 ${ }^{+}$PB B cells were investigated. Among 10 cells analyzed, $2 \mathrm{~V}_{\mathrm{K}} \mathrm{J}_{\mathrm{K}}$ joints showed 2 mutations each, whereas the remaining rearranged $V_{k}$ genes were identical to their corresponding germline genes (Fig. 2 and Table II). This result indicates that the majority of $\mathrm{CD}^{+} \mathrm{B}$ cells in healthy humans carry unmutated $\mathrm{V}$ genes.

Since the finding of two slightly mutated $\mathrm{V}$ genes in the analysis of $\mathrm{CD}^{+} \mathrm{CD} 19^{+} \mathrm{PB} \mathrm{B}$ cells might imply that a subset of $\mathrm{CD}^{+} \mathrm{B}$ cells carries mutated $\mathrm{V}$ genes, we sought a way to identify such a putative subpopulation. In man, $\mathrm{CD}^{+} \mathrm{B}$ cells are found among IgM-expressing, but not among isotypeswitched PB B lymphocytes (Figs. 3 and 4) (40). The $\operatorname{IgM}^{+} \mathrm{PB}$ B cell compartment consists of $\sim 90-95 \% \operatorname{IgM}^{+} \operatorname{IgD}^{+}$B cells that harbor predominantly unmutated $\mathrm{V}$ region genes $(15,17)$, and of about $5-10 \%$ IgM-only B cells, the majority of which were shown to carry mutated $\mathrm{V}$ gene rearrangements (31). Both of these subsets contain a fraction of CD5-expressing B lymphocytes ( $\sim 20$ and 10\%, respectively) (Fig. 4). Thus, if $\mathrm{CD}^{+} \mathrm{B}$ cells harboring mutated $\mathrm{V}$ genes exist, one might expect to find them within the IgM-only population.

Single IgM-only and single $\operatorname{IgM}^{+} \operatorname{IgD}^{+} \mathrm{B}$ cells of the CD5positive fraction were isolated from $\mathrm{PB}$ of two donors, and rearranged $\mathrm{V}_{\mathrm{K}}$ genes were amplified and sequenced. Whereas all 19 cells of the $\mathrm{IgM}^{+} \mathrm{IgD}^{+} \mathrm{CD}^{+} \mathrm{B}$ cell subset showed unmutated $\mathrm{V}_{\mathrm{K}}$ rearrangements, 3 of the $19 \mathrm{IgM}$-only $\mathrm{CD5}^{+} \mathrm{B}$ cells analyzed carried slightly mutated $V_{\kappa} J_{\kappa}$ joints (Figs. 5 and 6 and
Table II). In contrast, mutated $\mathrm{V}_{\mathrm{K}}$ region genes were obtained from 14 out of 17 cells of the control population, i.e., IgM-only $\mathrm{CD}^{-} \mathrm{B}$ cells. The fraction of B cells harboring mutated $V_{k}$ genes of the latter subset was significantly larger than were the respective fractions of the $\mathrm{IgM}$-only $\mathrm{CD}^{+}$and $\mathrm{IgM}^{+} \mathrm{IgD}^{+}$ $\mathrm{CD}^{+}$subsets $(P<0.001$ and $P<0.001$, respectively $)$. On the other hand, the difference in the proportion of mutated among all cells between the $\mathrm{IgM}$-only $\mathrm{CD}^{+}$and the $\mathrm{IgM}^{+} \mathrm{IgD}^{+} \mathrm{CD}^{+}$ subset (3/19 versus 0/19) did not reach statistical significance $(P=0.115)$. Owing to the overlap of $\mathrm{CD}^{+}$and $\mathrm{CD}^{-} \mathrm{B}$ cell subsets, we consider it likely that the mutated cells of the IgMonly $\mathrm{CD}^{+}$fraction are due to cellular contamination of IgMonly $\mathrm{CD}^{-}$memory B cells.

Nevertheless, we cannot exclude the possibility that mutated $\mathrm{CD}^{+} \mathrm{B}$ cells exist infrequently in humans. On the assumption that the mutated $\mathrm{CD}^{+} \mathrm{B}$ cells in this analysis do not represent contaminating conventional IgM-only memory B cells, the frequency of mutated $\mathrm{CD}^{+} \mathrm{B}$ cells in human $\mathrm{PB}$, based on the results of this study, can be estimated as follows: $90-95 \%$ of $\mathrm{CD}^{+} \mathrm{B}$ cells express both IgM and IgD; all of those cells analyzed carried unmutated $V_{\kappa}$ region genes (Figs. 5 and 6 and Table II); and 5-10\% of $\mathrm{CD}^{+}$B lymphocytes represent IgMonly B cells, $16 \%$ of which were mutated (Figs. 5 and 6 and Table II). As a result, the frequency of mutated cells would be $<2 \%$ of all $\mathrm{CD}^{+} \mathrm{PB} \mathrm{B}$ cells. We conclude, therefore, that the vast majority of $\mathrm{PB} \mathrm{CD}^{+} \mathrm{B}$ cells express unmutated $\mathrm{V}$ region genes. The finding that tonsillar $\mathrm{CD}^{+} \mathrm{B}$ cells show the same isotype distribution as do $\mathrm{PB} \mathrm{CD} 5^{+} \mathrm{B}$ cells (see Figs. 3, 4, and 7) implies that this conclusion also holds true for $\mathrm{CD}^{+} \mathrm{B}$ cells of secondary lymphoid organs.

This sequence analysis shows that IgM-only PB B cells in humans are composed of two separate subsets; $\mathrm{CD}^{-}$(conventional) memory $\mathrm{B}$ cells harboring mutated $\mathrm{V}$ genes, and a small fraction of $\mathrm{CD}^{+} \mathrm{B}$ cells carrying unmutated $\mathrm{V}$ genes. Whether the two subsets of $\mathrm{CD}^{+} \mathrm{B}$ cells analyzed in this study, i.e., IgM-only and $\mathrm{IgM}^{+} \mathrm{IgD}^{+} \mathrm{CD}^{+} \mathrm{B}$ cells, differ in other aspects than the level of $\mathrm{IgD}$ expression, remains unclear.

$C D 5^{+} B$ cells involved in diseases can be somatically mutated. B-CLL, small lymphocytic lymphoma, and some cases of prolymphocytic leukemia are considered to represent malignancies of $\mathrm{CD}^{+} \mathrm{B}$ cells. Although early studies of antibody genes expressed in B-CLL and small lymphocytic leukemia suggested that the tumor B cells carry unmutated $\mathrm{V}$ genes (6367 ), it has become clear that a considerable fraction of cases of CD5-positive B-CLL and prolymphocytic leukemia harbor somatically mutated $\mathrm{V}$ region genes $(25-28,68-70)$. In addition, mutated $\mathrm{V}$ genes were also found in each of six EBV-immortalized, flow-cytometrically isolated $\mathrm{CD}^{+} \mathrm{B}$ cells producing high-affinity, monoreactive autoantibodies derived from patients suffering from autoimmune diseases $(5,6)$. Thus, $\mathrm{CD}^{+}$ $B$ cells involved in autoimmunity and/or B cell malignancy frequently harbor somatically mutated $\mathrm{V}$ genes.

$C D 5^{+} B$ cells drawn into a $G C$ reaction in rare instances may be at an increased risk to become involved in autoimmunity and/or B cell malignancy. The frequent occurrence of mutated $\mathrm{CD}^{+} \mathrm{B}$ cells in disease contrasts with the finding of this analysis, that the $\mathrm{CD}^{+} \mathrm{B}$ cell population of healthy individuals is characterized by unmutated $\mathrm{V}$ region genes. How can this apparent discrepancy be explained?

One possibility would be that the disease-involved CD5expressing B cells are not derived from $\mathrm{CD}^{+} \mathrm{B}$ cells, but rep- 
resent conventional $\mathrm{B}$ cells that began to express CD5 on the cell surface after they left the GC. This hypothesis finds support in the observation that CD5 expression can be induced on conventional B cells in vitro (9).

One can also, however, envision an alternative scenario (see reference 8 ). $\mathrm{CD}^{+} \mathrm{B}$ cells represent a population of cells, many of which produce low-affinity, poly- and autoreactive antibodies (4). These cells usually do not participate in T celldependent immune reactions, and hence do not establish GCs. In rare cases, however, $\mathrm{CD}^{+} \mathrm{B}$ cells may be drawn into a $\mathrm{GC}$ reaction, and within this microenvironment, undergo somatic hypermutation. Through this process, low-affinity autoantibodies may give rise to high-affinity, pathogenic autoantibodies, as they have been detected in patients suffering from autoimmune diseases $(5,6)$. The vigorous clonal expansion of GC B cells and the processes of somatic hypermutation and class switch recombination may put the long-lived $\mathrm{CD}^{+} \mathrm{B}$ cells (71) at an increased risk for malignant transformation, because these activities may raise the chance to acquire transforming events. As a consequence, cases with mutated $\mathrm{V}$ genes would be overrepresented among B-CLLs.

The assumption that $\mathrm{CD}^{+} \mathrm{B}$ cells normally do not participate in GC reactions is supported by transfer experiments in the mouse that showed that $\mathrm{CD}^{+} \mathrm{B}$ cells only poorly reconstitute GCs $(8,72)$. In addition, these results argue against the possibility that $\mathrm{CD}^{+} \mathrm{B}$ cells may establish GCs, and upon doing so, lose CD5 expression, thereby generating $\mathrm{CD}^{-} \mathrm{GC}$ descendants. The scenario discussed in the previous paragraph finds further support by many similarities between the tumor cells in $\mathrm{CD}^{+} \mathrm{B}-\mathrm{CLL}$ and $\mathrm{CD}^{+} \mathrm{B}$ cells, indicating their derivation from $\mathrm{CD}^{+}$and not from conventional B cells (73). Collectively, the aspects mentioned here support the view that $\mathrm{CD}^{+} \mathrm{B}$ cells, only in rare instances proliferate and mutate within a GC, but if they do so, they are at an increased risk to become involved in immune dysfunctions.

\section{Acknowledgments}

We thank Christoph Göttlinger for help with the FACS, Andreas Thiel for help with the FACS-figures, Christoph Fischer for assistance with statistical analysis, and Klaus Rajewsky for stimulating discussion and critical reading of the manuscript.

This work was supported by the Deutsche Forschungsgemeinschaft through grants Di184/9, SFB243, and SFB502. Matthias Fischer was recipient of a scholarship of the Studienstiftung des deutschen Volkes.

\section{References}

1. Kipps, T.J. 1989. The CD5 B cell. Adv. Immunol. 47:117-185.

2. Bhat, N.M., A.B. Kantor, M.M. Bieber, A.M. Stall, L.A. Herzenberg, and N.N.H. Teng. 1992. The ontogeny and functional characteristics of human B-1 (CD5+ B) cells. Int. Immunol. 4:243-252.

3. Gadol, N., and K.A. Ault. 1986. Phenotypic and functional characterization of human LEU1 (CD5) B cells. Immunol. Rev. 93:23-34.

4. Casali, P., and A.L. Notkins. 1989. Probing the human B-cell repertoire with EBV: polyreactive antibodies and CD5+ B lymphocytes. Ann. Rev. Immunol. 7:513-535.

5. Harindranath, N., I.S. Goldfarb, H. Ikematsu, S.E. Burastero, R.L. Wilder, A.L. Notkins, and P. Casali. 1991. Complete sequence of the genes encoding the $\mathrm{VH}$ and $\mathrm{VL}$ regions of low- and high-affinity monoclonal IgM and IgA1 rheumatoid factors produced by CD5 + B cells from a rheumatoid arthritis patient. Int. Immunol. 3:865-875.

6. Mantovani, L., R.L. Wilder, and P. Casali. 1993. Human rheumatoid B-1a (CD5+ B) cells make somatically hypermutated high affinity IgM rheumatoid factors. J. Immunol. 151:473-488.
7. Kasaian, M.T., and P. Casali. 1995. B-1 cellular origin and VH segment structure of IgG, IgA, and IgM anti-DNA autoantibodies in patients with systemic lupus erythematosus. Ann. NY Acad. Sci. 764:410-423.

8. Stall, A.M., S.M. Wells, and K.P. Lam. 1996. B-1 cells: unique origins and functions. Semin. Immunol. 8:45-59.

9. Wortis, H.H., M. Teutsch, M. Higer, J. Zheng, and D.C. Parker. 1995. B-cell activation by crosslinking of surface IgM or ligation of CD40 involves alternative signal pathways and results in different B-cell phenotypes. Proc. Natl. Acad. Sci. USA. 92:3348-3352.

10. Arnold, L.W., C.A. Pennell, S.K. McCray, and S.H. Clarke. 1994. Development of B-1 cells: segregation of phosphatidyl choline-specific B cells to the B-1 population occurs after immunoglobulin gene expression. J. Exp. Med. 179:1585-1595.

11. Hayakawa, K., R.R. Hardy, L.A. Herzenberg, and L.A. Herzenberg. 1985. Progenitors for Ly-1 B cells are distinct from progenitors for other B cells. J. Exp. Med. 161:1554-1568.

12. Hayakawa, K., R.R. Hardy, A.M. Stall, L.A. Herzenberg, and L.A. Herzenberg. 1986. Immunoglobulin-bearing B cells reconstitute and maintain the murine Ly-1 B cell lineage. Eur. J. Immunol. 16:1313-1316.

13. Kantor, A.B., A.M. Stall, S. Adams, K. Watanabe, and L.A. Herzenberg. 1995. De novo development and self-replenishment of B cells. Int. Immunol. 7:55-68.

14. Kocks, C., and K. Rajewsky. 1989. Stable expression and somatic hypermutation of antibody $\mathrm{V}$ regions in B-cell developmental pathways. Ann. Rev. Immunol. 7:737-759.

15. Klein, U., R. Küppers, and K. Rajewsky. 1993. Human $\operatorname{IgM}^{+} \operatorname{IgD}^{+}$B cells, the major $B$ cell subset in the peripheral blood, express $V_{k}$ genes with no or little somatic mutation throughout life. Eur. J. Immunol. 23:3272-3277.

16. Klein, U., R. Küppers, and K. Rajewsky. 1994. Variable region gene analysis of B cell subsets derived from a 4-year-old child: somatically mutated memory B cells accumulate in the peripheral blood already at young age. $J$. Exp. Med. 180:1383-1393.

17. Pascual, V., Y.J. Liu, A. Magalski, O. de Bouteiller, J. Banchereau, and J.D. Capra. 1994. Analysis of somatic mutation in five B cell subsets of human tonsil. J. Exp. Med. 180:329-339.

18. Kelsoe, G. 1995. In situ studies of the germinal center reaction. Adv. Immunol. 60:267-288.

19. Jacob, J., G. Kelsoe, K. Rajewsky, and U. Weiss. 1991. Intraclonal generation of antibody mutants in germinal centres. Nature (Lond.). 354:389-392.

20. Berek, C., A. Berger, and M. Apel. 1991. Maturation of the immune response in germinal centers. Cell. 67:1121-1129.

21. Küppers, R., M. Zhao, M.L. Hansmann, and K. Rajewsky. 1993. Tracing $\mathrm{B}$ cell development in human germinal centres by molecular analysis of single cells picked from histological sections. EMBO J. 12:4955-4967.

22. Förster, I., H. Gu, and K. Rajewsky. 1988. Germline antibody V regions as determinants of clonal persistence and malignant growth in the B cell compartment. EMBO J. 7:3693-3703.

23. Tarlinton, D., A.M. Stall, and L.A. Herzenberg. 1988. Repetitive usage of immunoglobulin $\mathrm{VH}$ and D gene segments in CD5+ Ly-1 B clones of (NZB $\times$ NZW)F1 mice. EMBO J. 7:3705-3710.

24. Pennell, C.A., T.J. Mercolino, T.A. Grdina, L.W. Arnold, G. Haughton, and S.H. Clarke. 1989. Biased immunoglobulin variable region gene expression by Ly-1 B cells due to clonal selection. Eur. J. Immunol. 19:1289-1295.

25. Cai, J., C. Humphries, A. Richardson, and P.W. Tucker. 1992. Extensive and selective mutation of a rearranged VH5 gene in human B cell chronic lymphocytic leukemia. J. Exp. Med. 176:1073-1081.

26. Hashimoto, S., M. Dono, M. Wakai, S.L. Allen, S.M. Lichtman, P. Schulman, V.P. Vinciguerra, M. Ferrarini, J. Silver, and N. Chiorazzi. 1995. Somatic diversification and selection of immunoglobulin heavy and light chain variable region genes in $\mathrm{IgG}+\mathrm{CD} 5+$ chronic lymphocytic leukemia B cells. $J$. Exp. Med. 181:1507-1517.

27. Efremov, D.G., M. Ivanovski, N. Siljanovski, G. Pozzato, L. Cevreska, F. Fais, N. Chiorazzi, F.D. Bastista, and O.R. Burrone. 1996. Restricted immunoglobulin $\mathrm{VH}$ region repertoire in chronic lymphocytic leukemia patients with autoimmune hemolytic anemia. Blood. 87:3869-3876.

28. Johnson, T.A., L.Z. Rassenti, and T.J. Kipps. 1997. Ig VH1 genes expressed in B cell chronic lymphocytic leukemia exhibit distinctive molecular features. J. Immunol. 158:235-246.

29. Ebeling, S.B., M.E.M. Schutte, and T. Logtenberg. 1993. The majority of human tonsillar CD5+ B cells express somatically mutated Vk4 genes. Eur. J. Immunol. 23:1405-1408.

30. Ebeling, S.B., M.E.M. Schutte, and T. Logtenberg. 1993. Peripheral human CD5+ and CD5- B cells may express somatically mutated VH5- and VH6-encoded IgM receptors. J. Immunol. 151:6891-6899.

31. Klein, U., R. Küppers, and K. Rajewsky. 1997. Evidence for a large compartment of IgM-expressing memory B cells. Blood. 89:1288-1298.

32. Huber, C., H.G. Klobeck, and H.G. Zachau. 1992. Ongoing $V_{k}-J_{k}$ recombination after formation of a productive $\mathrm{V}_{\mathrm{K}}-\mathrm{J}_{\mathrm{K}}$ coding joint. Eur. J. Immunol. 22:1561-1565.

33. Betz, A.G., C. Milstein, A. Gonzalez-Fernandez, R. Pannell, T. Larson, and M.S. Neuberger. 1994. Elements regulating somatic hypermutation of an immunoglobulin $\kappa$ gene: critical role for the intron enhancer/matrix attachment 
region. Cell. 77:239-248.

34. Schäble, K.F., and H.G. Zachau. 1993. The variable region genes of the human immunoglobulin к locus. Biol. Chem. Hoppe-Seyler. 374:1001-1022.

35. Cox, J.P.L., I.M. Tomlinson, and G. Winter. 1994. A directory of human germ-line Vk segments reveals a strong bias in their usage. Eur. J. Immunol. 24: $827-836$

36. Grey, H., and M.J. Mannik. 1965. Specificity of recombination of $\mathrm{H}$ and L chains of human IgG-myeloma proteins. J. Exp. Med. 122:619-632.

37. Gay, D., T. Saunders, S. Camper, and M. Weigert. 1993. Receptor editing: an approach by autoreactive B cells to escape tolerance. J. Exp. Med. 177: 999-1008.

38. Chapple, M.R., I.C.M. MacLennan, and G.D. Johnson. 1990. A phenotypic study of B lymphocyte subpopulations in human bone marrow. Clin. Exp. Immunol. 81:166-172.

39. Jelinek, D.F., J.B. Splawski, and P.E. Lipsky. 1986. Human peripheral blood B lymphocyte subpopulations: functional and phenotypic analysis of surface IgD positive and negative subsets. J. Immunol. 136:83-92.

40. Irsch, J., S. Irlenbusch, J. Radl, P.D. Burrows, M.D. Cooper, and A. Radbruch. 1994. Switch recombination in normal IgA1+ B lymphocytes. Proc. Natl. Acad. Sci. USA. 91:1323-1327.

41. Feddersen, R.M., D.J. Martin, and B.G. van Ness. 1990. The frequency of multiple recombination events occuring at the human $\mathrm{Ig} \kappa \mathrm{L}$ chain locus. $J$. Immunol. 144:1088-1093.

42. Küppers, R., M. Hajadi, L. Plank, K. Rajewsky, and M.L. Hansmann. 1996. Molecular Ig gene analysis reveals that monocytoid B-cell lymphoma is a malignancy of mature B cells carrying somatically mutated $\mathrm{V}$ region genes and indicates that rearrangement of the kappa deleting element (resulting in deletion of the Ig kappa enhancers) abolishes somatic hypermutation in the human. Eur. J. Immunol. 26:1794-1800.

43. Hieter, P.A., J.V. Maizel, and P. Leder. 1982. Evolution of immunoglobulin $\kappa$ J region genes. J. Biol. Chem. 257:1516-1522.

44. Lee, S.K., S.L. Bridges, W.J. Koopman, and H.W. Schroeder. 1992. The immunoglobulin kappa light chain repertoire expressed in the synovium of a patient with rheumatoid arthritis. Arth. Rheum. 35:905-913.

45. Barbas, C.F., T.A. Collet, W. Amberg, P. Roben, J.M. Binley, D. Hoekstra, D. Cababa, T.M. Jones, R.A. Williamson, G.R. Pilkington, N.L. Haigwood, E. Cabezas, A.C. Satterthwait, I. Sanz, and D.R. Burton. 1993. Molecular profile of an antibody response to HIV-1 as probed by combinatorial libraries. J. Mol. Biol. 230:812-823.

46. Weber, J., G. Blaison, T. Martin, A. Knapp, and J. Pasquali. 1994. Evidence that the VkIII gene usage is nonstochastic in both adult and newborn peripheral B cells and that peripheral CD5+ adult B cells are oligoclonal. J. Clin. Invest. 93:2093-2105.

47. Klein, R., R. Jaenichen, and H.G. Zachau. 1993. Expressed human immunoglobulin $\kappa$ genes and their hypermutation. Eur. J. Immunol. 23:3248-3271.

48. Hayakawa, K., R.R. Hardy, D.R. Parks, and L.A. Herzenberg. 1983. The Ly-1 B cell subpopulation in normal, immunodefective, and autoimmune mice. J. Exp. Med. 157:202-218.

49. Gu, H., I. Förster, and K. Rajewsky. 1990. Sequence homologies, N sequence insertion and $\mathrm{JH}$ gene utilization in VHDJH joining: implications for the joining mechanism and the ontogenetic timing of Ly1 B cell and B-CLL progenitor generation. EMBO J. 9:2133-2140.

50. Feeney, A.J. 1990. Lack of $\mathrm{N}$ regions in fetal and neonatal mouse immunoglobulin V-D-J junctional sequences. J. Exp. Med. 172:1377-1390

51. Kantor, A.B., C.E. Merrill, L.A. Herzenberg, and J.L. Hillson. 1997. An unbiased analysis of VH-D-JH sequences from B-1a, B-1b, and conventional B cells. J. Immunol. 158:1175-1186.

52. Schroeder, H.W., and J.Y. Wang. 1990. Preferential utilization of conserved immunoglobulin heavy chain variable gene segments during human fetal life. Proc. Natl. Acad. Sci. USA. 87:6146-6150.

53. Sanz, I. 1991. Multiple mechanisms participate in the generation of diversity of human H chain CDR3 regions. J. Immunol. 147:1720-1729.

54. Kiyoi, H., K. Naito, R. Ohno, and T. Naoe. 1995. Comparable profiles of the immunoglobulin heavy chain complementarity determining region (CDR)-3 in CD5+ and CD5- human cord blood B lymphocytes. Immunology. 85:236-
240

55. Bridges, S.L., S.K. Lee, M.L. Johnson, J.C. Lavelle, P.G. Fowler, W.J. Koopman, and H.W. Schroeder. 1995. Somatic mutation and CDR3 lengths of immunoglobulin $\kappa$ light chains expressed in patients with rheumatoid arthritis and in normal individuals. J. Clin. Invest. 96:831-841.

56. Gadol, N., M.A. Peacock, and K.A. Ault. 1988. Antigenic phenotype and functional characterization of human tonsil B cells. Blood. 71:1048-1055.

57. Sanz, I., P. Casali, J.W. Thomas, A.L. Notkins, and J.D. Capra. 1989. Nucleotide sequences of eight human natural autoantibody VH regions reveals apparent restricted use of VH families. J. Immunol. 142:4054-4061.

58. van der Heijden, R.W.J., H. Bunschoten, V. Pascual, F.G.C.M. Uytdehaag, A.D.M.E. Osterhaus, and J.D. Capra. 1990. Nucleotide sequence of a human monoclonal anti-idiotypic antibody specific for a rabies virus-neutralizing monoclonal idiotypic antibody reveals extensive somatic variability suggestive of an antigen-driven immune response. J. Immunol. 144:2835-2839.

59. Schutte, M.E.M., S.B. Ebeling, K.E. Akkermans, F.H.J. Gmelig-Meyling, and T. Logtenberg. 1991. Antibody specificity and immunoglobulin VH gene utilization of human monoclonal CD5+ B cell lines. Eur. J. Immunol. 21: $1115-1121$.

60. Dono, M., S. Zupo, R. Masante, G. Taborelli, N. Chiorazzi, and M. Fer rarini. 1993. Identification of two distinct $\mathrm{CD}^{-} \mathrm{B}$ cell subsets from human tonsils with different responses to CD40 monoclonal antibody. Eur. J. Immunol. 23:873-881.

61. Nakamura, M., S.E. Burastero, A.L. Notkins, and P. Casali. 1988. Human monoclonal rheumatoid factor-like antibodies from CD5 (Leu-1) ${ }^{+}$B cells are polyreactive. J. Immunol. 140:4180-4186.

62. Küppers, R., A. Roers, and H. Kanzler. 1997. Molecular single cell studies of normal and transformed lymphocytes. Cancer Surv. In press.

63. Kipps, T.J., E. Tomhave, P.P. Chen, and D.A. Carson. 1988. Autoantibody-associated $\kappa$ light chain variable region gene expressed in chronic lymphocytic leukemia with little or no somatic mutation. J. Exp. Med. 167:840-852.

64. Pratt, L.F., L. Rassenti, J. Larrick, B. Robbins, P.M. Banks, and T.J. Kipps. 1989. Ig V region gene expression in small lymphocytic lymphoma with little or no somatic hypermutation. J. Immunol. 143:699-705.

65. Küppers, R., A. Gause, and K. Rajewsky. 1991. B cells of chronic lymphatic leukemia express V genes in unmutated form. Leuk. Res. 15:487-496.

66. Rassenti, L.Z., and T.J. Kipps. 1993. Lack of extensive mutations in the VH5 genes used in common B cell chronic lymphocytic leukemia. J. Exp. Med. 177:1039-1046.

67. Wagner, S.D., and L. Luzzatto. 1993. Vк gene segments rearranged in chronic lymphocytic leukemia are distributed over a large portion of the $\mathrm{V}_{\mathrm{K}}$ locus and do not show somatic mutation. Eur. J. Immunol. 23:391-397.

68. Schroeder, H.W., and G. Dighiero. 1994. The pathogenesis of chronic lymphocytic leukemia: analysis of the antibody repertoire. Immunol. Today. 15: 288-294.

69. Korganow, A.S., T. Martin, J.C. Weber, B. Lioure, P. Lutz, A.M. Knapp, and J.L. Pasquali. 1994. Molecular analysis of rearranged VH genes during B cell chronic lymphocytic leukemia: intraclonal stability is frequent but not constant. Leuk. Lymphoma. 14:55-69.

70. Davi, F., K. Maloum, A. Michel, O. Pritsch, C. Magnac, E. Macintyre, F. Salomon-Nguyen, J.L. Binet, G. Dighiero, and H. Merle-Béral. 1996. High frequency of somatic mutations in the $\mathrm{VH}$ genes expressed in prolymphocytic leukemia. Blood. 88:3953-3961.

71. Rajewsky, K., I. Förster, and A. Cumano. 1987. Evolutionary and somatic selection of the antibody repertoire in the mouse. Science (Wash. DC). 238:1088-1094.

72. Linton, P.-J., D. Lo, L. Lai, G.J. Thorbecke, and N.R. Klinman. 1992. Among naive precursor cell subpopulations only progenitors of memory B cells originate germinal centers. Eur. J. Immunol. 22:1293-1297.

73. Caligaris-Cappio, F. 1996. B-chronic lymphocytic leukemia: a malignancy of anti-self B cells. Blood. 87:2615-2620.

74. Kabat, E., T. Wu, H. Bilofsky, M. Reid-Miller, H. Perry, and K. Gottesmann. 1987. Sequences of Proteins of Immunological Interest. US Govt. Printing Office, Bethesda, MD. 